http://artnodes.uoc.edu

ARTICLE

"MEDIA LIBRARIES AND ARCHIVES FOR THE 21ST CENTURY" NODE

\title{
The World is Just a Great Big (Archive) Onion
}

\author{
Mike Stubbs \\ Director and CEO of FACT \\ (Foundation for Art and Creative Technology)
}

Submission date: November, 2010

Accepted date: December, 2010

Published in: December, 2010

\begin{abstract}
The article reflects on some of the key challenges that the new possibilities of archives and databases have brought us in the context of media art, as much as for all cultural productions. The utopia of infinite storage, the re-empowerment of viewer as producer, the collective tagging practice, the need for a narrative able to construct meaning from the excess of data, or the creation of a particular view of the world through the mediation of cultural objects are some of the issues explored in this article. Through the experience of FACT as a cultural institution dealing with many of the key issues treated here, the article affirms the need for an articulation of a view of the past able to introduce media art practices in the context of art and cultural history, and speculates around the new paradigm for archiving today.
\end{abstract}

\section{Keywords}

living archive, digital storytelling, collaboration, Wodiczko, metadata

\section{El mundo no es más que una cebolla grande (en forma de archivo)}

\section{Resumen}

El artículo reflexiona sobre algunos de los desafíos principales que comportan las nuevas opciones de archivos y bases de datos en el contexto del arte multimedia, así como para todas las producciones culturales. La utopía del almacenamiento infinito, la reconquista del poder del espectador como productor, la práctica colectiva de etiquetar, la necesidad de una narrativa capaz de elaborar sentido a partir del exceso de datos o la creación de una visión particular del mundo a través de la mediación de los objetos culturales son algunos de los temas que se exploran en este artículo. Tomando como base la experiencia de FACT como institución cultural que aborda muchos de los temas clave planteados en el mismo, se afirma la necesidad de articular una visión del pasado que logre introducir las prácticas del arte multimedia en el contexto de la historia del arte y de la cultura, y se especula en torno al nuevo paradigma actual de archivo.

\section{Palabras clave}

archivo vivo, narrativa digital, colaboración, Wodiczko, metadatos 


\section{artnodes 8}

http://artnodes.uoc.edu

The World is Just a Great Big (Archive) Onion

Our vision and understanding of the world is as much informed through memory and comparative data as it is through our eyes. Within a media landscape proliferating images and with enhanced accessibility to network and archive, Total Recall has become a possibility. This suggests the re-empowerment of the viewer to navigate and select images within the context of a global database, thus converting viewer into producer - continuously uploading and collectively informing that representation of the world -. It appears a collaborative model of documenting and perceiving is upon us. Or is this an illusion?

The classic questions of who edits history and how information and artefacts are selected for preservation, conservation and archive still sits with us, however the shift towards a culture or technical system in which everything is archive is tantalizing. Until we have better trust in those systems and are confident that all data is uploaded and tagged, Total Upload remains a utopian dream and the realities of handling dusty materials for import or cumbersome computers containing data. Resourcing this with humans is a real issue, too. Not only for non-robotic labour: engineering and operating a keyboard, but also in terms of selecting and contextualizing that to be archived.

The technologies of surveillance today allow us to trawl far greater data sets than the KGB could during the Cold War. Yet how do we act, when we can access everything? If we archive everything, how will we find the time to access and make sense of it? Similarly, what timescales are appropriate for storing this information?

Everything forever? Infinite storage, infinite choice and no limits of time or space. Perhaps. It is already not just about what to archive - but how to archive - . Storage systems and mechanisms need embedded transcoding and transfer ability that is integrated from the start. Metadata tagging and transcoding have as much in common with technologies of virtual engineering as with archiving media art. The issues we face here in media art histories are shared across many disciplines; future-proofing data within an emergent condition is both part of our task and intrinsic to our practice. We are all tied into an up-grade culture that makes previously "new formats" obsolescent far too quickly, whether as domestic consumers or professional archivists. Data needs to be considered as having a DNA of its own that can mutate and jump species as necessary and our digital heritage has to move beyond the container.

Until the movement to real-time cognitive enhancement we will still need judgment in forming opinion and much as we want hard facts, we still love stories, desire fantasy and find illusion compelling. The suspension of disbelief is deeply encoded and we can be gullible beings even when everything is before us and information is presented to us. Many of us know that driving cars is dangerous or that we can view medical photographs of ruined lungs knowing that cigarettes will kill us, yet we continue to drive and smoke (sometimes even at the same time!). Access to raw information is useful, but how knowledge is formed through comparison of positions and opinions remains critical. Can creating an archive without developing a narrative or historicising the contents be of the same value? Producing an evidence base is of course dependent on having access to the artefacts and data that form our history: therefore collecting, conserving and archiving are the key factors in more traditional museumological cannons. But when artefacts and data are proliferating, mutating and selfgenerating - this traditional approach is less relevant and we need new terms and references; this itself is a massive challenge when applying conventional ways of considering the role of institutions be they museums, galleries or libraries.

When data has become the lifeblood of our cognition and memory, re-defining vision and ultimately begging the question: how does vision persist after death? Have we become members of the CIA - the Collective Intelligence Agency? Is the latest version of the networked condition already here, or is this a transitionary state of becoming or a continual emergence? William Gibson inspired me when discussing such far-reaching questions as well as popularising cyberspace in his classic cyberpunk novel, Neuromancer.

Cyberspace. A consensual hallucination experienced daily by billions of legitimate operators, in every nation, by children being taught mathematical concepts... A graphic representation of data abstracted from banks of every computer in the human system. Unthinkable complexity. Lines of light ranged in the nonspace of the mind, clusters and constellations of data. Like city lights, receding... (Gibson, 1984, p. 69)

Over the last twenty years, facts have become less definitive and increasingly speculative. Have we then become less certain of the future, or is it that modernism and the promise of "progress" has not always come up trumps? Most versions of science fiction and futurism tend to dumb-down. Facebook and Twitter may be the current ubiquitous manifestations of collective intelligence, but by the time you read this, will they already sound quaint and old hat? And with the development of ever speedier methods of exchanging information and comparing views, does this synchronous flow take account of bias, differences of perception, and diversity of culture?

Bearing this in mind, it is not possible to compare perceptions across time and generalise about "one" world, or certainly not until everyone has access to the internet, education in social media and PDAs. ${ }^{1}$ My grandfather related stories of "deepest, darkest Africa, the Amazon and shrunken heads". Living a bread-and-jam existence in the shadow of rationing, post-war Britain needed hope. And as a product of that time, I have been privileged to have filmed in zero

1. More than eight million citizens in the UK have no access to computer or internet (more than $10 \%$ of the population). 


\section{artnodes 8}

http://artnodes.uoc.edu

The World is Just a Great Big (Archive) Onion

gravity and am planning an artists' residency programme on the moon. The unimaginable really has gotten closer and my father is now one of the savvy elder generation who does pay electricity bills online.

Access to new tools and new skills has enabled new models of living. A perfect example of this is our own community TV station Tenantspin, which over the past ten years has seen people of different ages and backgrounds creating their own media, TV station and archive exploring compelling new relationships as both producer and audience. Formed initially in 2001 by Danish artists group Superflex and initially a cable TV station managed by residents in public housing it has now become so much more than that. ${ }^{2}$

A relational exchange, whether televised or otherwise, is only as good as the energy put into it. This is about real people in real life rather than technology itself. We increasingly accept the broad philosophical premise that we create the world in perceiving it, or at least that objects, circumstances, events and data are affected through mediation.

Conversely, with the shift from conventional perceptions of broadcast and narrowcast, time and space have been upended. Entire systems of belief and dogma have tumbled along with previous understanding and measurement of time: Time Collapse. We may no longer have the resources to upload everything. FACT, like many media art institutions, is under restrictions on income and it is very hard to prioritise conserving the past over investing in new ideas and people; therefore, the necessity to create automated instruments and data supply chains becomes critical. And with the burgeoning mass of collectable data this also creates a problem of how to forget...

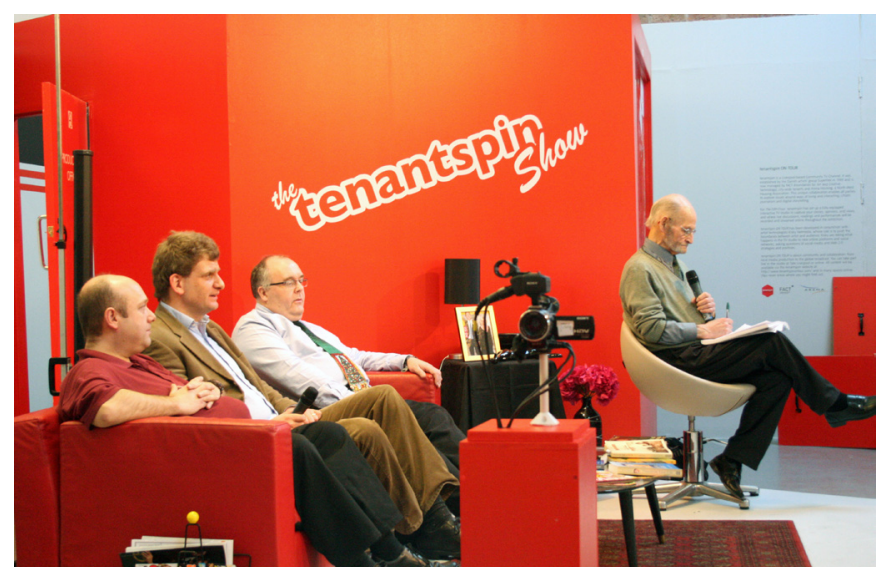

Image 1. The Tenantspin show
The notion of the traditional archive may be redundant but for now remains essential. FACT Archive is both a physical and online collection of tapes and related materials charting an early history of predominantly UK video art and international works commissioned for FACT programmes, ranging from documentation of commissions and interviews with luminaries such as Vito Acconci through to the ephemera and promotional materials produced for the earliest video festival Video Positive in 1989. ${ }^{3}$

Originally built from scratch, initially in partnership with $A$ Database, combining search and database facilities and taken inhouse for further development. Whilst we wait for automation, we have hit that point like many archives where through financial pressure we have prioritised the present and future over the past. We no longer have an archive manager or archivist, but we have however migrated many of the technologies and thinking into developing FACT TV. ${ }^{4}$

The idea of a living archive existing alongside a traditional archive is of great interest. FACT hosts and partners collaborative PHD students with both via Liverpool John Moores University and the University of Liverpool. PhD subjects cover Media Art History, The History of FACT, Digital Art in the Public Realm and Film and Architecture. Being able to bring together a collaborative resource of historic material utilising facilities such as FACT TV makes for an interesting approach to using online platforms when combining academic and practice based research with artists' projects. An example of this would be the residency of Krzysztof Wodiczko as part of last years AND (Abandon Normal Devices) Festival. ${ }^{5}$

Every aspect of Wodiczko's project War Veteran Vehicle integrated story-telling, archive, digital technology and art in public space. To enhance this further, through capturing participants' views within the FACT TV environment; built depth and complexity and in many ways suggests living archive made real. This was a brilliant art project a true and necessary collaboration, specific in its starting point of hearing the stories of returning soldiers from Iraq and Afghanistan in partnership with Combat Stress, a charity set up to help with veterans mental health. Wodiczko has made a lifetime art practice deeply connected to the voiceless finding space to express themselves and "knowing when to speak out".

With the ending of the Cold War, previously powerful assumptions were further challenged and it became increasingly possible for us to hear new voices. With these shifts, traditional systems of knowledge transfer, pedagogies and histories were put into question, significantly weakening bastions of traditional power. This, and peerto-peer information exchange, has to a considerable extent, replaced broadcasting.

2. See: $<\mathrm{http}: / /$ www.tenantspin.org/>.

3. See: $<$ http://archive.fact.co.uk/>.

4. See: $<$ http://fact.tv/>.

5. See: $<$ http://fact.tv/search?content_search_simple=true\&content_wordss=wod\&submit.x=0\&submit.y=0>. 


\section{artnodes 8}

As the world's geo-political axis has shifted, so too has FACT. Indeed, if Liverpool has dubbed itself the centre of the creative universe, perhaps FACT has been one of the axes around which that creativity has revolved and evolved. The FACT Centre may originally have been conceived as a technocentric media arts centre, but it has blossomed through love, time and need into a true $21^{\text {st }}$ century arts centre; the embodiment of contemporary hybrid research and practice-based knowledge exchange, rich in participation, forging strong, deep - and essentially social - connections to a wide range of communities and places. The fascination here is the real-time negotiation of those relationships and nuanced interchanges which motivate communication, exchange and action. It is through comparing differences that we learn. The process and comparison of what is both out there and in here is the end in itself. The idea that art can be a container for meaning, or directly representational, is less and less interesting as methods of direct translation prevail. Direct experience and transmission suggest colourless technical and non-ideologised

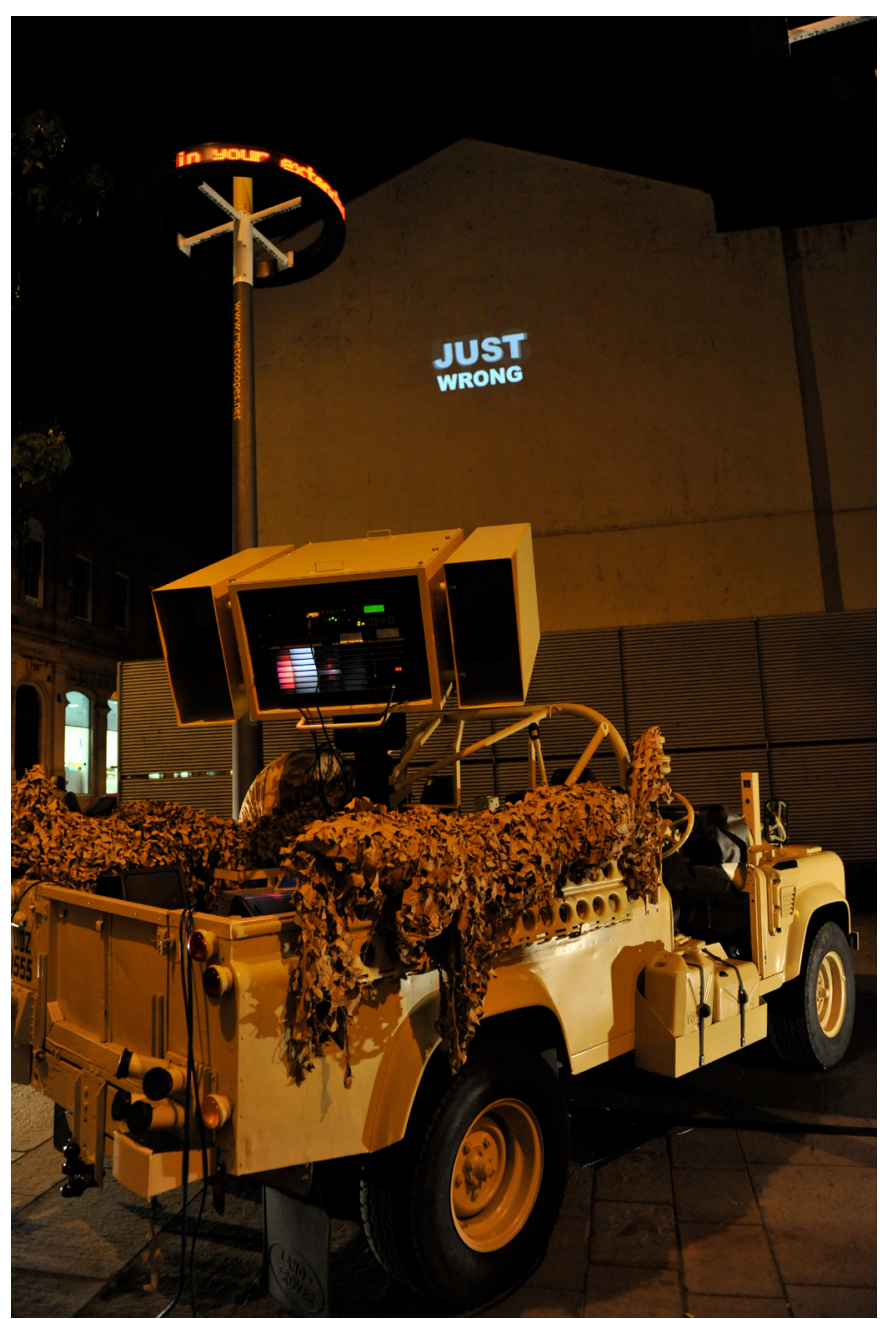

Image 2. War Veteran Vehicle Project

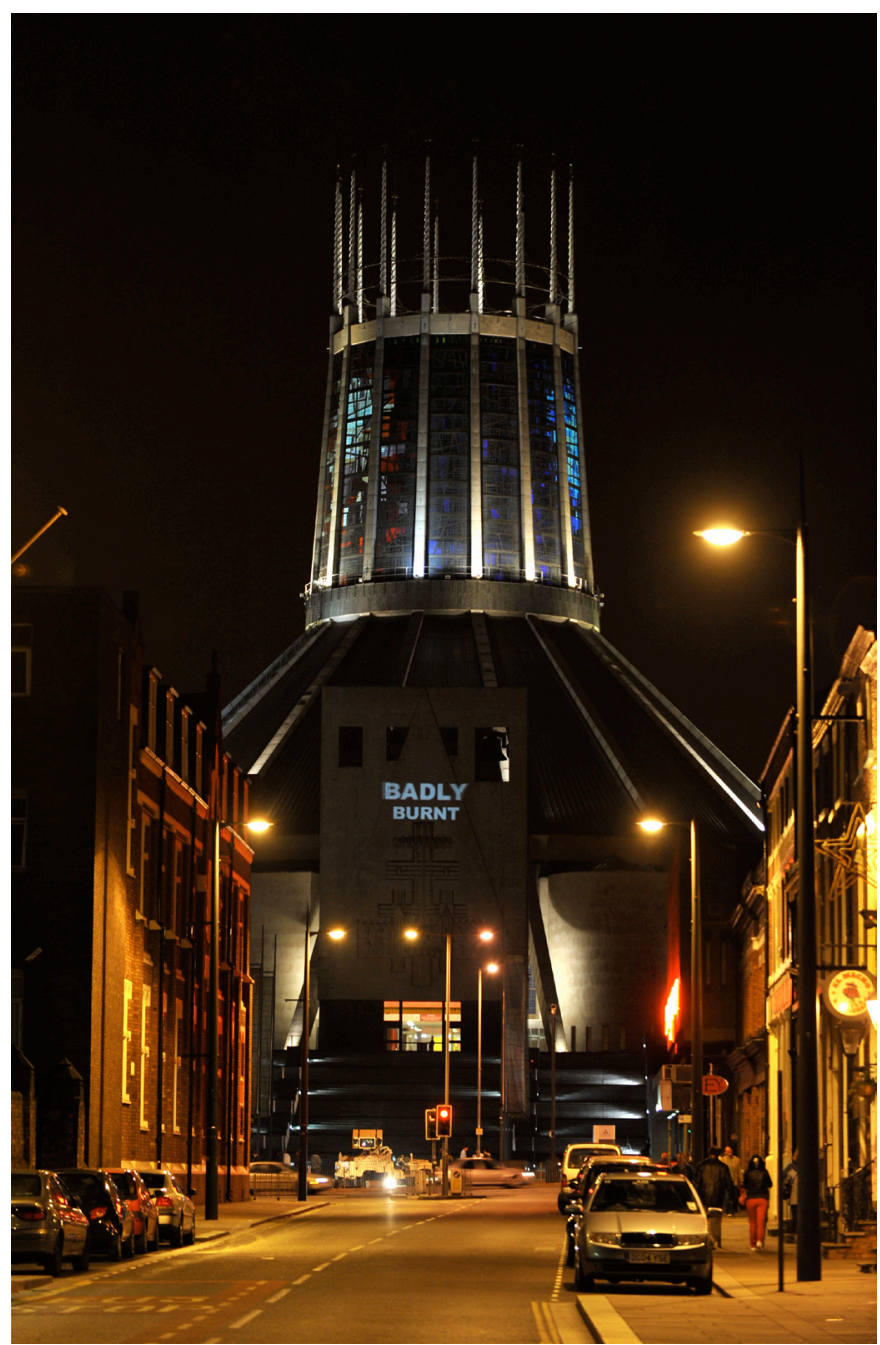

Image 3. War Veteran Vehicle projection on Liverpool Catholic Cathedral

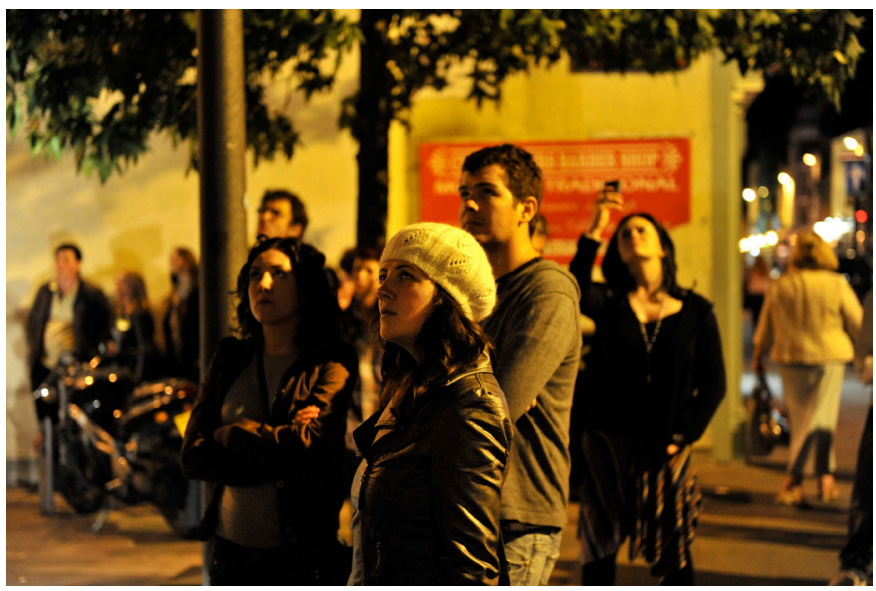

Image 4. People watching the projections 


\section{artnodes 8}

http://artnodes.uoc.edu

The World is Just a Great Big (Archive) Onion

decision-making, but let's reference some of our current debates around sustainability and look to the scale of economies that exploit resources whilst abstracting their origins, some call it greenwash.

An ontological approach is where art excels, and artists' work that is of observation and direct experience proves difficult to measure and quantify.

Twenty years ago artists, curators and activists were not knowingly creating a new paradigm or starting a "digital" revolution. It is only now that we can rationalise post facto and reassemble those connections. This is important not only to ensure our place in history, but to also remind ourselves of where innovation often begins: with the experiments of artists, designers and technologists. FACT actively encourages experimentation, provocation and interference. Repeatedly it has been artists who have provided early warnings of the cultural, economic and political ramifications of new technologies, through a variety of media and tactics, gesture, performance and resistance.

Equally, it is our responsibility to acknowledge the importance of diverse historical practices, contextualising media art and its histories in relation to the current explosion within digital and networked society. In demonstrating the significance of pioneering practices by artists, technologists, curators and our partners, we can chart how these influenced and helped to form emergent models of organisation and the application of peer-to-peer communication technologies, social media and personalisation opportunities across a variety of sectors and in the new networked conditions. The ramifications of these types of video, media art and new media art practices have extended well beyond the development of discrete artworks, questions of genre and the practice of art. While these are important areas in themselves, even more significant is the fact that video, media and new media art have been forerunners in what is now termed a digital revolution - a revolution that is redefining all rules of engagement, collaboration and economy -. Beyond the body, beyond biology and technology, posthuman, we are dispersed across time and space, wearing multiple data-bodies in a chaotic matrix, joined as one ceramic ribbon through silicon chips and virtual memory.

If artists since Futurism have embraced exponential acceleration, complex power systems and traditional politics of argument are now becoming increasingly indigestible, reduced to sound bites and spectacle, giving little comfort where specialism and volume and sheer quantity of data are overwhelming. Without trust in knowbots, robots, basic forms of artificial intelligence and ubiquitised filters, increasingly we must trust our instincts and the direct experience:

For to perceive, a beholder must create his own experience. And his creation must include relations comparable to those which the original producer underwent... Without an act of recreation the object is not perceived as a work of art. (Dewey, 2005, p. 54)

Art is about being, about being actively involved and about doing it. The artists who have made FACT what it is have had little choice in this; it is their life and they are the living archive.

We invent the society we want to belong to. We are the real-time experiment but let's not forget how we remember the past, or where we put it.

\section{Reference}

GIBSON, William (1984). Neuromancer. New York: Ace Books

DEWEY, John (2005). Art as Experience (First published in 1934). New York: The Berkeley Publishing Group.

\section{Recommended Citation}

STUBBS, Mike (2010). "The World is Just a Great Big (Archive) Onion". In: "Media Libraries and Archives for the 21st Century" [online node]. Artnodes. No. 10. UOC

[Accessed: $\mathrm{dd} / \mathrm{mm} / \mathrm{yy}]$. $<$ http://artnodes.uoc.edu/ojs/index.php/artnodes/article/view/artnodes-n10-stubbs/ artnodes-n10-stubbs-eng>

ISSN 1695-5951

This article is - unless indicated otherwise - covered by the Creative Commons Spain Attribution 3.0 licence. You may copy, distribute, transmit and adapt the work, provided you attribute it (authorship journal name, publisher) in the manner specified by the author(s) or licensor(s). The full text of the licence can be consulted here: $h$ ttp://creativecommons.org/licenses/by/3.0/es/deed.en 


\section{artnodes 8}

http://artnodes.uoc.edu

The World is Just a Great Big (Archive) Onion

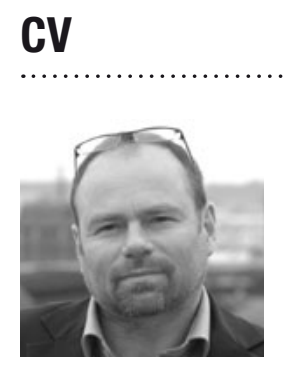

\section{Mike Stubbs}

Director and CEO of FACT

(Foundation for Art and Creative Technology)

mike.stubbs@fact.co.uk

FACT

(Foundation for Art and Creative Technology)

88 Wood Street

Liverpool

L1 4DQ

Director and CEO of FACT since May 2007, jointly appointed by Liverpool John Moores University as Professor of Art, Media and Curating. Encompassing a broad range of arts and media practice, his arts management, curating and artwork have been internationally acknowledged.

As founding Director at Hull Time Based Arts (HTBA) his work won recognition as a primary promoter of new media and performance art in an international context, setting up the venue Time Base, EMARE (European Media Arts Residency Exchange) and the international R00T Festival.

Mike moved to Melbourne in 2003 to the world-leading Australian Centre for Moving Image (ACMI) as Curatorial Manager, becoming Head of Exhibitions the following year. An award-winning and respected moving image artist, Mike Stubbs' work encompasses film, video, mixed media installations, performance and curation. He has won more than a dozen international awards, including first prizes at the Oberhausen and Locarno Film Festivals, and in 1999 was invited to present a video retrospective of his work at Tate Gallery, London. A selection of his work was featured at the 2003 Adelaide International Film Festival.

During his career, Mike has commissioned over 250 interactive, site specific, performative, sonic and moving-image based artworks. Originally educated at the Royal College of Art and Cardiff College of Art, Mike's own internationally commissioned artwork encompasses broadcast films, video art, large-scale public projections and new media installation, much made through a process of interdisciplinary research and residency.

Mike arrived at FACT in the final lead up to Liverpool's year as European Capital of Culture 2008, with the opportunity to work with other cultural leaders in further developing Liverpool as a major international cultural centre and destination.

FACT itself is an engine for the production and presentation of cutting edge moving image and new media art, whose work Mike is intent on refocusing through experience, consciousness, articulation and building-wide programming via interdisciplinary partnerships. For more information about FACT, visit: <http:// www.fact.co.uk>.

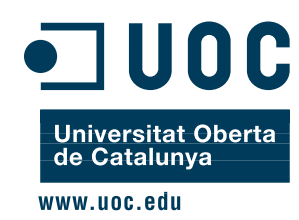

www.uoc.edu labu미미

Centro de Arte y Creación Industrial 